\title{
Effects of Thermal Water Upwelling on Microclimate Change in the High Geo-Temperature Roadway
}

\author{
Junhui Wang $\mathbb{D}^{1},{ }^{1}$ Zhijun Wan $\mathbb{D}^{1},{ }^{1}$ Hongwei Zhang $\mathbb{D},{ }^{2}$ Jingchao Wang, $^{1}$ Yi Wang $\mathbb{D},{ }^{3}$ \\ Yuan Zhang, ${ }^{1}$ Sifei Liu, ${ }^{1}$ and Ning $\mathrm{Lu}^{4}$ \\ ${ }^{1}$ Key Laboratory of Deep Coal Resource Mining (CUMT), Ministry of Education of China, School of Mines, \\ China University of Mining and Technology, Xuzhou, Jiangsu 221116, China \\ ${ }^{2}$ School of Energy and Mining Engineering, China University of Mining and Technology, Beijing 100083, China \\ ${ }^{3}$ College of Safety and Emergency Management Engineering, Taiyuan University of Technology, Taiyuan, Shanxi 030024, China \\ ${ }^{4}$ Dananhu No. 1 Coal Mine, CHN Energy Investment Group Co., Ltd., Hami 839000, China
}

Correspondence should be addressed to Zhijun Wan; zhjwan@cumt.edu.cn and Hongwei Zhang; hongwei@cumtb.edu.cn

Received 5 October 2020; Revised 29 October 2020; Accepted 23 February 2021; Published 3 March 2021

Academic Editor: Junfei Zhang

Copyright ( 2021 Junhui Wang et al. This is an open access article distributed under the Creative Commons Attribution License, which permits unrestricted use, distribution, and reproduction in any medium, provided the original work is properly cited.

\begin{abstract}
Deep-circling thermal water upwelling and trickling to high geo-temperature roadway obviously alter the microclimate in mines, which brings difficulty to the prediction of airflow temperature and humidity. This is the basis of air-conditioning cooling load calculation. The heat and mass transfer between trickling water and airflow is rather complicated. Moreover, humid air exhibits the accumulation effect of heat and humidity in the long-distance flow process. In this paper, an apparatus was designed and developed to explore the influence of thermal water trickling on the airflow thermal parameters of a section of roadway $(1 L-39 L$, in which $1 L-9 L$ is the trickling section). The results show the following (1) With the rise of trickling water temperature, the total enthalpy difference of dry air in the roadway increases within a small range and that of humid air goes up nonlinearly. Besides, the increase of trickling water flow rate has an insignificant effect on the sensible heat of the airflow, while it plays a notable role in increasing the latent heat of the airflow. (2) High trickling water temperature results in a higher growth rate of humidity ratio at $19 \mathrm{~L}$ than those at $29 \mathrm{~L}$ and $39 \mathrm{~L}$ in the early stage of thermal water trickling. Meanwhile, sensible heat exchange, which becomes strong after thermal water trickles for over $30 \mathrm{~min}$, complicates the enthalpy difference variation rates of wet air at the three measuring points. (3) The three measuring points in the $19 \mathrm{~L}-39 \mathrm{~L}$ section all display a process of enthalpy growth with time. In the case of point $39 \mathrm{~L}$, the enthalpy difference of humid air surges sharply when the trickling water temperature is $80^{\circ} \mathrm{C}$ or the flow rate is $200 \mathrm{ml} / \mathrm{min}$. The research results boast some reference value for thermal water management and microclimate change forecasting after the airflow passes through a trickling roadway.
\end{abstract}

\section{Introduction}

Mine thermal hazards are one of the geological disasters on a global scale [1-4]. During deep mining, roadways are often excavated in surrounding rock with high geo-temperature field, which will inevitably bring about thermal hazards because heat dissipation of the rock is one of the main heat sources of roadways $[5,6]$. Mine microclimate parameters, including temperature, humidity, and enthalpy, are the essential indicators for evaluating the severity of thermal hazards. There are 47 coal mines whose depths exceed
$1,000 \mathrm{~m}$ in China [7, 8], such as Jiahe Coal Mine $(1,200 \mathrm{~m})$, Suncun Coal Mine $(1,500 \mathrm{~m})$, and Tangkou Coal Mine $(1,025 \mathrm{~m})$. Airflow temperatures of these mines are mostly higher than $30^{\circ} \mathrm{C}$ (Table 1) so that the operating environment for workers is rather harsh. Slight thermal hazards can usually be solved by means of thermal insulation and ventilation adjustment, while serious thermal hazards have to be dealt with by the mine air-conditioning system that cools the airflow directly [9]. The required cooling amount and the cooling capacity of conditioners are calculated based on the actual measurement and dynamic prediction of 
TABLE 1: Incomplete statistics of thermal hazards of mines in China [13].

\begin{tabular}{|c|c|c|c|c|c|c|}
\hline Region & Coal mine & $\begin{array}{c}\text { Mining } \\
\text { depth }(\mathrm{m})\end{array}$ & $\begin{array}{c}\text { Airflow } \\
\text { temperature }\left({ }^{\circ} \mathrm{C}\right)\end{array}$ & $\begin{array}{c}\text { Highest rock } \\
\text { temperature }\left({ }^{\circ} \mathrm{C}\right)\end{array}$ & $\begin{array}{c}\text { Geothermal } \\
\text { gradient }\left({ }^{\circ} \mathrm{C} / \mathrm{hm}\right)\end{array}$ & $\begin{array}{l}\text { Highest water } \\
\text { temperature }\left({ }^{\circ} \mathrm{C}\right)\end{array}$ \\
\hline \multirow{6}{*}{$\begin{array}{l}\text { Jiangsu } \\
\text { province }\end{array}$} & $\begin{array}{l}\text { Zhangshuanglou } \\
\text { Mine }\end{array}$ & 1000 & 35 & 40.6 & 4 & 30 \\
\hline & Sanhejian Mine & 1010 & 36 & 46.8 & 3.24 & 50 \\
\hline & Datun Mine & 1015 & 37 & 40.4 & $2.36-2.42$ & 26 \\
\hline & Qishan Mine & 1100 & 30 & 41.9 & 2.6 & \\
\hline & Jiahe Mine & 1200 & 36 & 40 & 2.21 & 30 \\
\hline & Zhangxiaolou Mine & 1200 & 33.5 & 42 & 1.64 & \\
\hline \multirow{9}{*}{$\begin{array}{l}\text { Anhui } \\
\text { province }\end{array}$} & Zhangji Mine & 1260 & & 51.5 & 2.65 & \\
\hline & Xinji No. 1 Mine & 550 & 33.6 & 36.4 & 3.2 & 35 \\
\hline & Panyi Mine & 650 & 36 & 40 & 3 & \\
\hline & Guqiao Mine & 800 & 36 & 40.1 & 3.08 & \\
\hline & Pansan Mine & 810 & 40 & 43 & 3.42 & \\
\hline & Dingji Mine & 826 & 40 & 43 & $2.52-4.02$ & \\
\hline & Wobei Mine & 700 & 36 & 35.5 & $1-4.2$ & 25 \\
\hline & Xieqiao Mine & 720 & 33 & 41.1 & $2-2.5$ & \\
\hline & Liuzhuang Mine & 900 & 34 & 38.5 & 3 & \\
\hline \multirow{9}{*}{$\begin{array}{l}\text { Shandong } \\
\text { province }\end{array}$} & Dongtan Mine & 660 & 31 & 33 & 2.3 & \\
\hline & Zhaolou Mine & 840 & 35 & 45 & 2.2 & \\
\hline & Jining No. 3 Mine & 838 & 33 & 35.3 & $2.44-2.96$ & 29 \\
\hline & Zhaoyang Mine & 880 & 32 & 34.2 & 2.11 & \\
\hline & Tangkou Mine & 1025 & 35 & 37 & 2 & 55 \\
\hline & Xiezhuang Mine & 1010 & 34 & 37 & 3 & 45 \\
\hline & Suncun Mine & 1500 & 35 & 48 & 2.7 & 45 \\
\hline & Xinjulong Mine & 900 & 39 & 44.7 & 3.23 & 47 \\
\hline & Huaheng Mine & 1200 & & 37 & 2.61 & \\
\hline \multirow{9}{*}{$\begin{array}{l}\text { Henan } \\
\text { province }\end{array}$} & $\begin{array}{l}\text { Pingdingshan No. } 4 \\
\text { Mine }\end{array}$ & 840 & 30 & 40 & 4 & \\
\hline & $\begin{array}{l}\text { Pingdingshan No. } 5 \\
\text { Mine }\end{array}$ & 909 & 35 & 50 & 3.6 & \\
\hline & $\begin{array}{c}\text { Pingdingshan No. } 6 \\
\text { Mine }\end{array}$ & 900 & 35 & 53 & 4.1 & \\
\hline & $\begin{array}{c}\text { Pingdingshan No. } 8 \\
\text { Mine }\end{array}$ & 660 & 35 & 43 & 3 & 62 \\
\hline & $\begin{array}{c}\text { Pingdingshan No. } 10 \\
\text { Mine }\end{array}$ & 960 & 32 & 39 & 4 & \\
\hline & $\begin{array}{c}\text { Pingdingshan No. } 13 \\
\text { Mine }\end{array}$ & 750 & 31 & 40 & 4.5 & \\
\hline & Zhaojiazhai Mine & 610 & 31 & & 3.5 & 32 \\
\hline & Yuejin Mine & 960 & 32 & & 2 & \\
\hline & Liangbei Mine & 680 & 30 & 37 & 2.87 & 42 \\
\hline $\begin{array}{l}\text { Chengjiao } \\
\text { Mine }\end{array}$ & 750 & 33 & 39 & 2.62 & 35 & \\
\hline \multirow{5}{*}{$\begin{array}{l}\text { Hebei } \\
\text { province }\end{array}$} & Wutongzhuang Mine & 680 & 30 & 35 & 2.9 & 45 \\
\hline & Cixi Mine & 1200 & 30 & 37 & 3 & \\
\hline & Qianjiaying Mine & 860 & 33 & 46 & $3-5.9$ & \\
\hline & Dacheng Coalfield & 1100 & 33 & 46 & $3-5.9$ & \\
\hline & Yangdong Minefield & 1500 & 33 & 46 & $3-5.9$ & \\
\hline \multirow{4}{*}{$\begin{array}{l}\text { Northeast } \\
\text { China }\end{array}$} & Loahutai Mine & 715 & 33 & 42 & $3.6-4.3$ & $48-51$ \\
\hline & Dongfeng Mine & 800 & 33 & 30 & $2.7-4.6$ & $48-51$ \\
\hline & Donghai Mine & 1100 & 34 & 39 & 3.7 & \\
\hline & $\begin{array}{c}\text { Hongyang No. } 3 \\
\text { Mine }\end{array}$ & 1050 & 38 & 43 & 4.3 & \\
\hline \multirow{2}{*}{$\begin{array}{l}\text { Ningxia } \\
\text { province }\end{array}$} & Yangchangwan Mine & 1100 & 32 & 37 & 3.36 & \\
\hline & Meihuajing Mine & 450 & 33 & 38 & 3.12 & \\
\hline $\begin{array}{l}\text { Guizhou } \\
\text { province }\end{array}$ & Dongshan Mine & 975 & 29.5 & 35 & 3.5 & \\
\hline $\begin{array}{l}\text { Hunan } \\
\text { province }\end{array}$ & Zhouyuanshan Mine & 1000 & 33 & 42.7 & 4.2 & \\
\hline
\end{tabular}


airflow temperature, which is a complex system engineering. Thermal water is common in some mines. On the one hand, it is a feasible resource and a potential approach to the utilization of geothermal energy under specific hydrogeothermal conditions. On the other hand, it can cause remarkable underground microclimate changes [10]. Thus, it needs to be managed rationally $[11,12]$. As shown in Table 1, the thermal water $\left(62^{\circ} \mathrm{C}\right)$ in Pingdingshan No. 8 Coal Mine notably heats the airflow and raises the temperature in working face to $35^{\circ} \mathrm{C}$. In addition, in Hujiawan Coal Mine, when the airflow passes through the trickling section, $82 \%$ of its heat increment is attributed to the thermal water $\left(40^{\circ} \mathrm{C}\right)$. Thus, the research on the heat and humidity transfer between airflow and high geo-temperature surrounding rock with thermal water trickling is of great significance for the prediction of mine microclimate and the design of airconditioning.

As the basis of airflow temperature prediction, heat and mass transfer between airflow and surrounding rock is a complex dynamic process. А. Н. Щербань defined this process as unstable heat transfer and used the dimensionless physical parameter $K_{\tau}$ to represent the process, but he did not give the theoretical solution of $K_{\tau}$ [13]. Numerous scholars have solved the coefficient of unstable heat transfer $K_{\tau}$ by means of the analytical solution method (Cen [14], Zhou [15]), the Laplace transform method (Sun [16], Yakovenko [17]), the separated variable method (Wang [18]), the numerical method (Qin [19], Roy [20]), and so forth. Nevertheless, these solution methods are of complicated processes because of the nonlinearity of thermal differential equations, and the results are lack of practicability. Wang et al. [21] obtained an empirical formula for $K_{\tau}$ by performing regression analysis on measured data. Cheng et al. [22] proposed a calculation model for $K_{\tau}$ prediction based on an improved momentum BP algorithm. In order to investigate the effect of roadway wall moisture on surrounding rock heat dissipation, Chow and Chung [23] adopted an experimental method to analyze the process of water evaporation from the roadway wall into the air, and they focused on the evaporation rate and conversion temperature. Hou and Shen [24] put forward the calculation formula for heat transfer between a partial wet roadway wall and the airflow. Liu et al. [25] and Gao et al. [26] calibrated $K_{\tau}$ by introducing the coefficient "roadway surface humidity." It can be seen that these studies mostly adopted theoretical analysis or numerical calculation methods, yet they failed to analyze the variation law of $K_{\tau}$ in depth. Consequently, the actual effect of changes in boundary conditions on heat and mass transfer is still difficult to be fully grasped. Thermal water trickling forms a liquid film in the roadway, and direct contact between air and water will cause heat and mass transfer. Scholars have conducted extensive research on spray room [27], cooling tower [28], steam cooler [29], and so forth in light of the film theory, but their research results are not quite applicable to roadways with trickling thermal water because airflow that has passed through the trickling section exhibits the accumulation effect of heat and humidity in the process of long-distance flow.
Despite the abundant progress made in the research on heat and moisture transfer between surrounding rock and airflow in dry or wet roadways, there are a few related studies on roadways with trickling thermal water. To study roadways with trickling thermal water, theoretical and numerical calculations can hardly be carried out because of the complex boundary conditions and the coefficient of heat and mass transfer that are difficult to determine. In contrast, similarity simulation experiments are more advantageous in the study on hydrodynamics and heat transfer. Wang et al. [30], Zhang et al. [31], Zhu et al. [32], and Wang [33] have designed experimental apparatuses for heat transfer between surrounding rock and airflow, but these apparatuses are just applicable to dry roadways. On the basis of previous studies, an improvement was made to the similar simulation apparatus independently developed by our team, so that the apparatus can be used for exploring the microclimate oscillation with trickling water. The improvement is of great significance for the prediction of underground climate conditions, the adjustment of the ventilation network, and the design of the air-conditioning system. Ultimately, it serves the treatment of mine thermal hazards.

In this paper, we focused on investigating the effects of thermal water trickling on thermal environment change in the high geo-temperature roadway. Firstly, the geological genesis of thermal hazards in Sanhejian Coal Mine was analyzed based on geological survey and field measurement. Then, with Sanhejian Coal Mine taken as the research background, an apparatus was designed and improved to explore the effect of thermal water trickling on a section of roadway. Finally, the temperatures, relative humidity $(\mathrm{RH})$, and enthalpy differences of the measuring points were presented and analyzed.

\section{Geological Genesis of Thermal Hazards: A Case Study}

2.1. Geological Structure and Strata of Sanhejian Coal Mine. Sanhejian Coal Mine is located in the southwest part of the secondary folds of Tengyu Anticline in the middle of Fengpei Coalfield, as shown in Figure 1. The regional faults developed in Fengpei Coalfield include the nearly EW-trending Yutai Fault, the NS-trending Jiaxiang Fault, and Sunshidian Fault (shattered zone width $38.5-51.53 \mathrm{~m}$ ). These faults, combined with other subordinated faults, cause the stepped fault blocks [34]. In the south boundary of Sanhejian Coal Mine, the east section is F1 Fault (shattered zone width $31-32.29 \mathrm{~m}$ ) and the west section is Liuwuzhuang Fault. The northeast boundary is the Sunshidian Fault, and the northwest is a monoclinic structure tilting to the deep part. A secondary fault F2 exists inside the minefield.

The stratigraphic conditions in Sanhejian Coal Mine are given in Table 2. The main mining seams of Sanhejian Coal Mine are 7\# and 9\# coal seams of Permian Period Shanxi Formation and 17\# and 21\# coal seams of Carboniferous Period Taiyuan Formation. The main aquifer is the limestone of the Ordovician Period Majiagou Formation. 


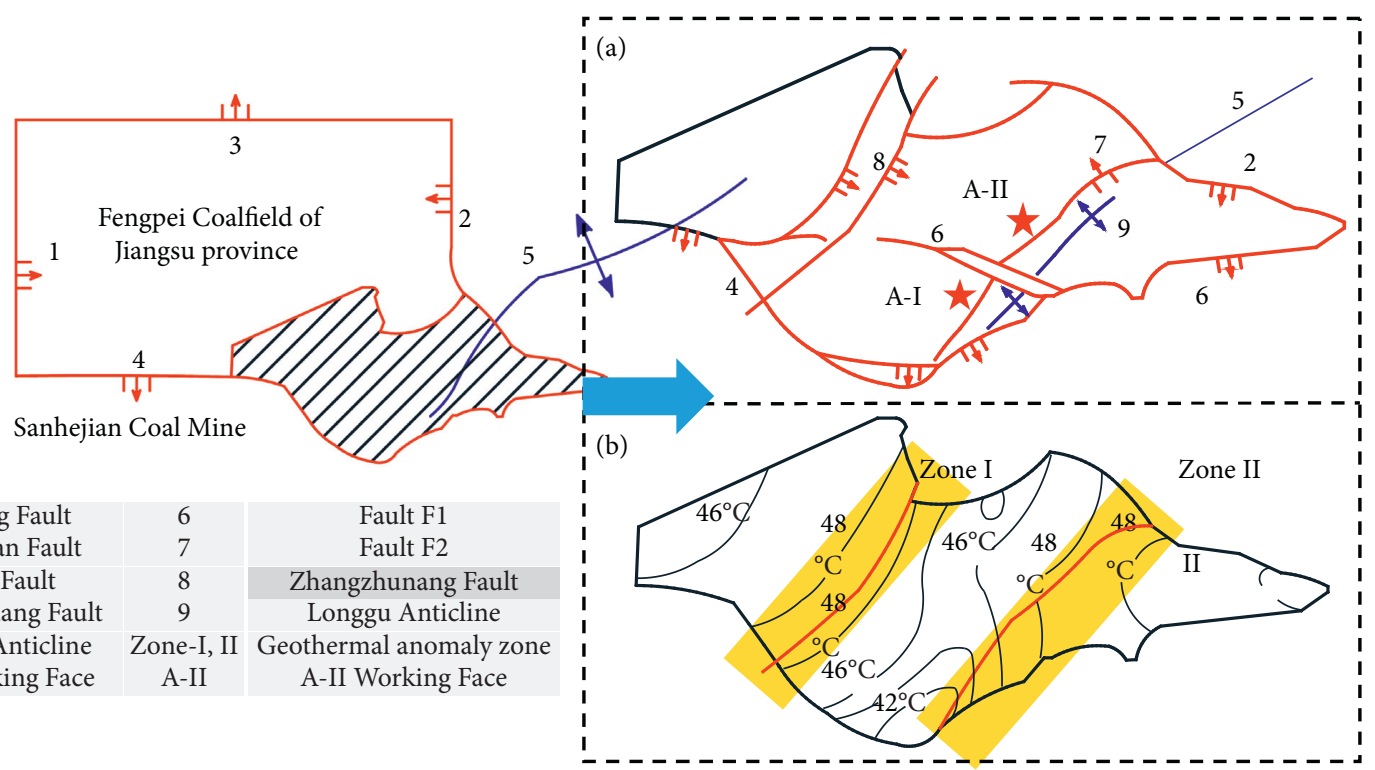

Figure 1: Sanhejian Coal Mine in China: (a) geological structure and (b) geothermal temperature isogram at the depth of $-980 \mathrm{~m}$.

TABle 2: Impermeability and thermal conductivity of strata in Sanhejian Coal Mine [34, 35].

\begin{tabular}{|c|c|c|c|c|c|c|c|c|}
\hline Era & Period & Code & Lithology & $\begin{array}{c}\text { Thickness } \\
(\mathrm{m})\end{array}$ & Aquosity & $\begin{array}{c}\text { Geothermal } \\
\text { gradient } \\
\left({ }^{\circ} \mathrm{C} / \mathbf{h m}\right)\end{array}$ & $\begin{array}{c}\text { Thermal } \\
\text { conductivity } \\
\mathbf{W} /(\mathbf{M} \cdot \mathbf{K})\end{array}$ & $\begin{array}{l}\text { Terrestrial } \\
\text { heat flow } \\
\left(\mathbf{m W} / \mathbf{m}^{2}\right)\end{array}$ \\
\hline Cenozoic & Quaternary & Q & Clay, sand & 220 & Weak & 3.5 & & \multirow{3}{*}{76.6} \\
\hline \multirow[t]{2}{*}{ Mesozoic } & Cretaceous & $\mathrm{K}$ & $\begin{array}{l}\text { Sandstone, } \\
\text { glutenite, } \\
\text { mudstone }\end{array}$ & \multirow[t]{2}{*}{391} & \multirow[t]{2}{*}{ Weak } & \multirow[t]{2}{*}{2.8} & \multirow[t]{2}{*}{2.74} & \\
\hline & Jurassic & $\mathrm{J}$ & $\begin{array}{l}\text { Sandstone, } \\
\text { mudstone }\end{array}$ & & & & & \\
\hline \multirow{3}{*}{ Paleozoic } & Permian & $\mathrm{P}$ & Mudstone, & \multirow[b]{2}{*}{536} & \multirow[b]{2}{*}{ Weak } & 3.3 & 2.28 & 75.1 \\
\hline & Carboniferous & $\mathrm{C}$ & $\begin{array}{l}\text { sandstone, coal, } \\
\text { limestone }\end{array}$ & & & 3.3 & 2.22 & 76.1 \\
\hline & Ordovician & $\mathrm{O}$ & $\begin{array}{l}\text { Limestone, } \\
\text { dolomite }\end{array}$ & $500-742$ & $\begin{array}{c}\text { Water abundance } \\
\text { and strong } \\
\text { permeability }\end{array}$ & & 2.94 & \\
\hline
\end{tabular}

\subsection{Geological Genesis of Thermal Hazards in Sanhejian Coal} Mine. Sanhejian Coal Mine is one of the mines suffering from thermal hazards in China [11]. In March 2018, the roadway airflow parameters in the ventilation route of A-I working face were measured (Figure 2). The temperature of the airflow increased from $7.2^{\circ} \mathrm{C}$ to $27^{\circ} \mathrm{C}$ (Figure $3(\mathrm{a})$ ). The $\mathrm{RH}$ at each measuring point was maintained above $85 \%$, and the $\mathrm{RH}$ in A-I working face approximated saturation. Thermal hazards in Sanhejian Coal Mine are mainly caused by high geo-temperature (HGT) field and thermal water upwelling (TWU).

The HGT field is mainly attributed to the regional geothermal background and the changes in heat transfer conditions in the shallow crust. (1) The average terrestrial heat flow in Sanhejian Coal Mine is $75.9 \mathrm{~mW} / \mathrm{m}^{2}$ (Table 2) which is higher than the global average $61.5 \mathrm{~mW} / \mathrm{m}^{2}$. (2) Affected by F2 Fault and Longgu Anticline near A-I working face, the crystalline basement and coal basement of the area have been uplifted, resulting in the heat flow accumulation at

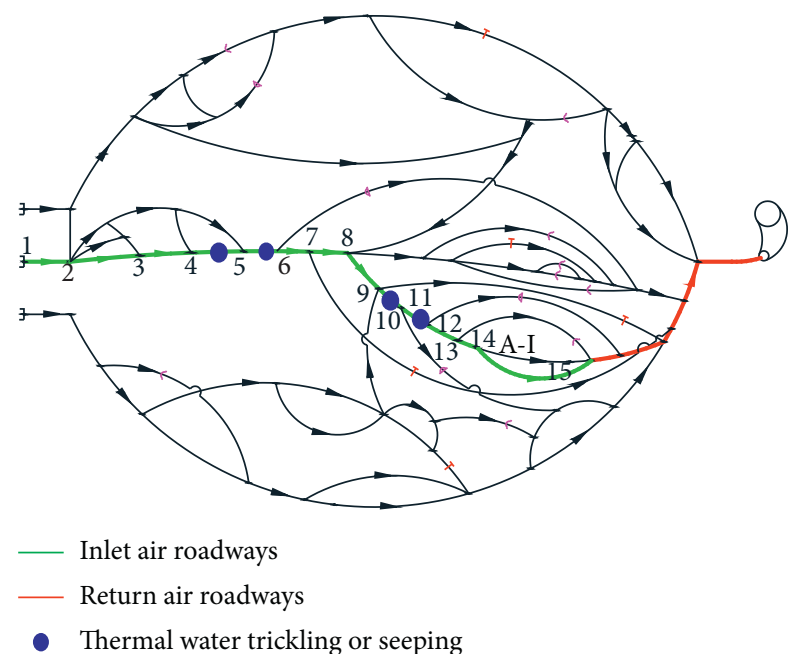

FIgURE 2: Ventilation route of the A-I working face in Sanhejian Coal Mine. 


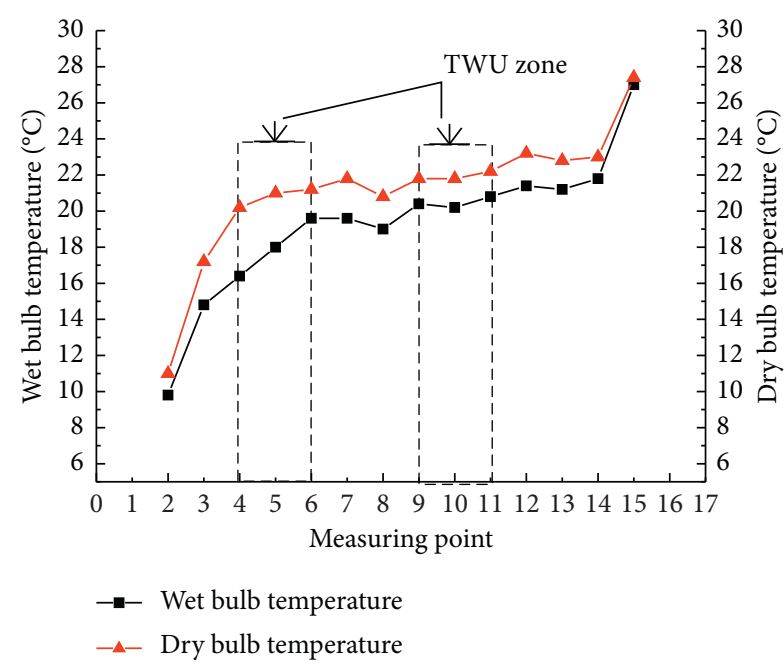

(a)

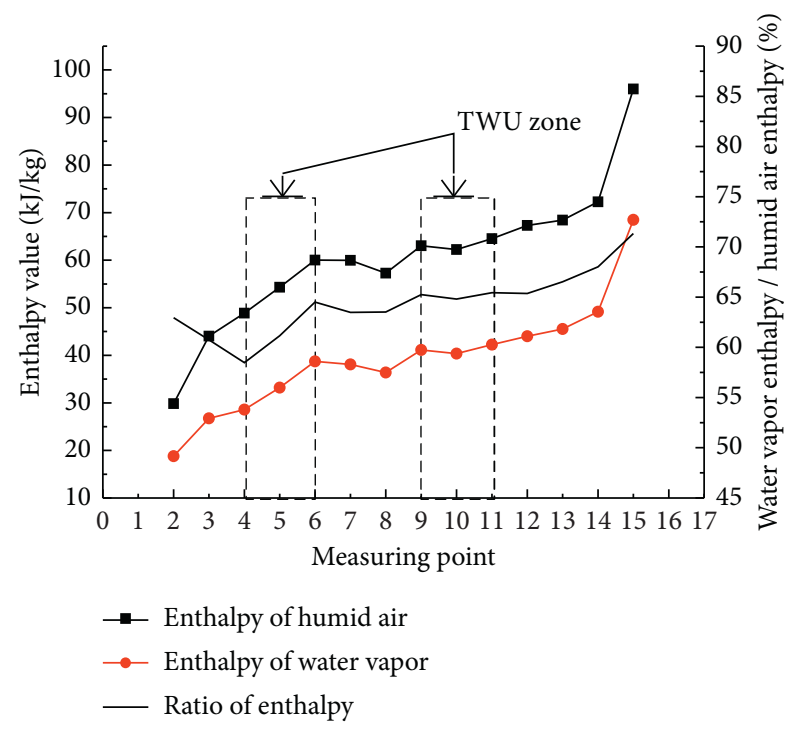

(b)

FIgURE 3: Measuring result of mine microclimate parameters.

the top of the anticline or at the uplifted part. Therefore, a large severe-anomaly zone of geo-temperature has been formed in this region (Zone II in Figure 1(b) [11]). (3) The Quaternary, Cretaceous-Jurassic, and CarboniferousPermian strata jointly form a good high thermal resistance cover (thickness $600-1200 \mathrm{~m}$ ) with poor aquosity and thermal conductivity (Table 2).

The additional heat source caused by the TWU along with the HGT field makes the mine climate more complex. It was a process of warming, humidifying, and enthalpy increasing along the ventilation route of A-I working face. As shown in Figures 2 and 3, the problem of thermal water trickling or seeping existed in the ventilation route. Consequently, the relative humidity and the humidity ratio (HR) are of large values (e.g., measuring point 6: $87 \% \mathrm{RH}, 0.015 \mathrm{~kg} / \mathrm{kg} \mathrm{HR}$ ); the ratio of water vapor enthalpy to humid air enthalpy reached $65 \%-71 \%$ (Figure 3(b)); the latent heat exchange of airflow accounted for a large part of the heat source.

The problem of TWU also exists in other areas of Sanhejian Coal Mine. For example, a water inrush with a temperature over $50^{\circ} \mathrm{C}$ and water pressure of $7.6 \mathrm{MPa}$ occurred in A-II working face in Figure 1 [36]. Where does thermal water in the roadway come from? Sunjiadian Fault is a large regional fault, but it has a small gap in Sanhejian Mine Field $(<100 \mathrm{~m})$ and is cut through by neotectonic faults (Figure 4). As a result, the Ordovician limestone aquifer is still capable of conducting water laterally. There is an Ordovician suboutcrop area in the axis of Tengyu Anticline. The water head difference between the water supply end and the water trickling end is as high as $980 \mathrm{~m}$, which provides dynamic for the radial flow and vertical upwelling of the Ordovician water. The neotectonic faults cut through the Ordovician strata and coal strata. Meanwhile, fracture propagation is promoted by mining activities. Then, the deep-circle water gets heated by the rock, upwells along the fault, and finally trickles to the roadway.

\section{Methodology}

As described in Section 2, the HGT field and the TWU have a significant impact on the mine climate. Airflow absorbs the heat released from surrounding rock along the roadway. However, the temperature and humidity of airflow will alter notably if thermal water trickling occurs at multiple positions in the route, which brings trouble to climate forecasting and ventilation management. In Section 3, an apparatus for heat and mass transfer in the modelling roadway was designed and developed, and the precast fracture representing the fracture zone connected with the roadway is supplied with water whose flow rate and temperature are controllable (Figure 4).

3.1. Experimental Apparatus. The experimental apparatus consists of a modelling HGT roadway, a pump, a water flow thermostat, a Surrounding Rock Heating System (SRHS), a Constant Temperature and Humidity Ventilator (CTHV), and a data acquisition system (Figures 4 and 5). The geometric similarity constant of the device $C_{l}=20$, the time similarity constant $C_{\tau}=400$, and the wind speed similarity constant $C_{v}=0.05$. Detailed design of the experimental apparatus can be found in the literature [31]. The modelling HGT roadway was composed of six cylinders ( $1 \mathrm{~m} /$ cylinder) that were poured (or filled) with materials similar to the surrounding rock. Temperature sensors were set at $1 R, 2 R$, $3 R$, and $4 R(R=0.1 \mathrm{~m})$ along the radial direction of the cylinder, and temperature and humidity sensors were set at 


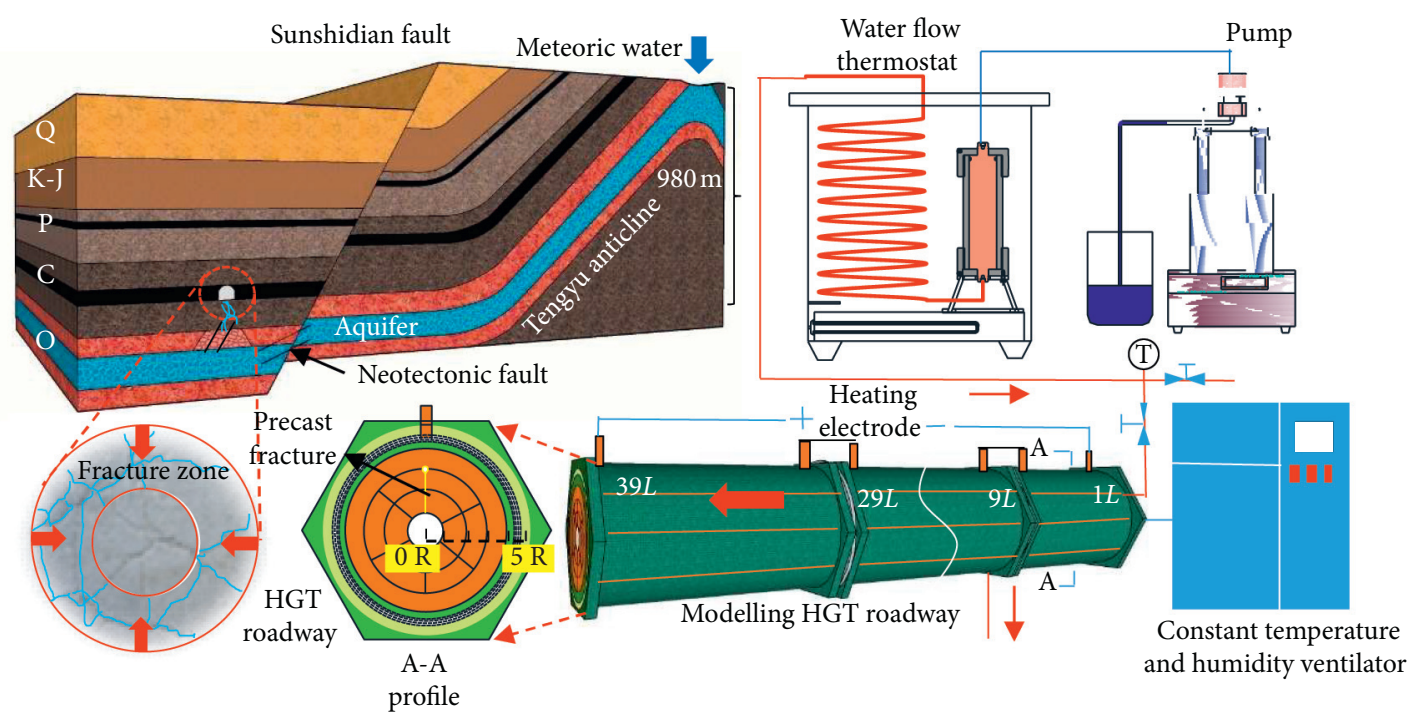

FIgURE 4: Experimental apparatus to modelling hot water trickling to roadway.

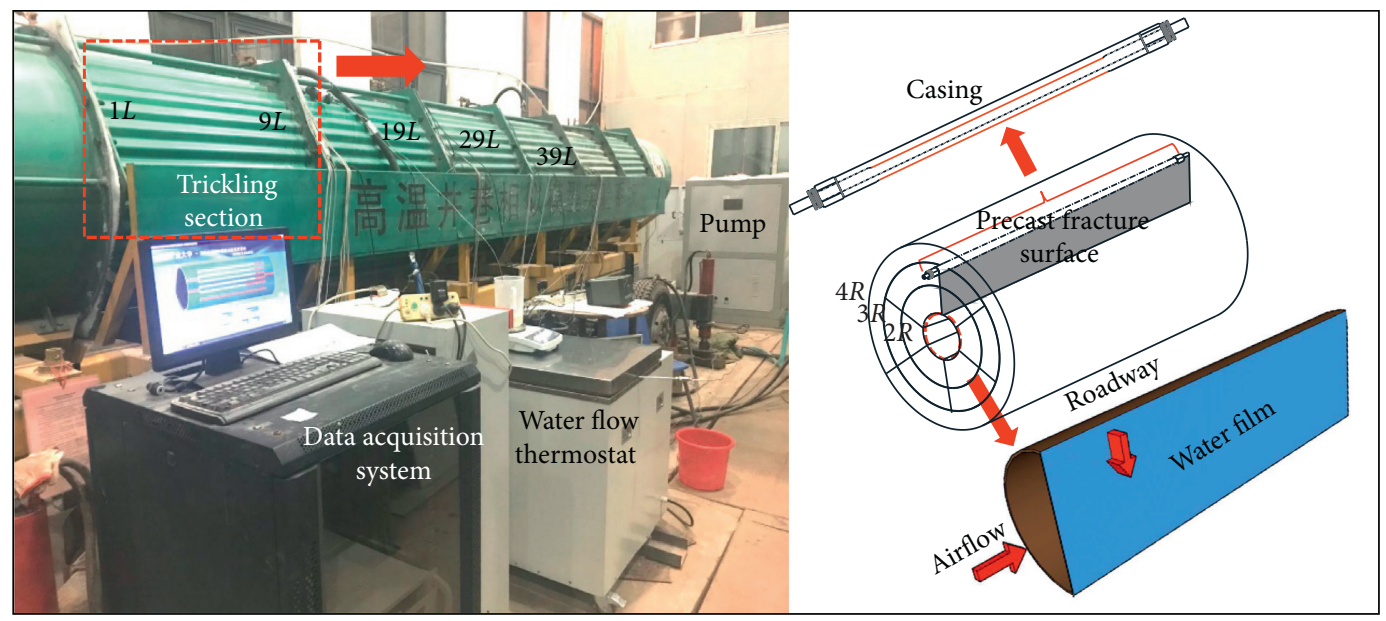

Figure 5: Preembedded seepage casing and precast fracture surface.

$1 L, 9 L, 19 L, 29 L$, and $39 L(L=0.1 \mathrm{~m})$ of the airflow axial centres. The pump and water flow thermostat provided the required water flow temperature and rate. The SRHS ensured the constant temperature of the virgin rock. The CTHV was responsible for keeping the inlet airflow steady.

The $1 L-9 L$ section in Figures 5 and 6 was the trickling water section. The casing (at $3 R$ in the cylinder) and the precast fracture surface were preembedded in the surrounding rock (Figure 5). The designed casing was a coaxial double-layered steel tube whose internal casing was slotted upward and external casing was slotted downward. Having overcome the surface tension, the surfactant-containing liquid flowed from the internal casing to the external one and finally entered the roadway along the fracture surface to form a water film.

The fracture surface (width $2 \mathrm{~mm}$, length $800 \mathrm{~mm}$ ) was equivalent to a $4 \mathrm{~cm}$ fracture zone of the mine, and the total length of the roadway and the length of the trickling section were $80 \mathrm{~m}$ and $16 \mathrm{~m}$, respectively.

\subsection{Experimental Contents and Procedures}

3.2.1. Experimental Contents. The virgin rock temperature and inlet airflow parameters in each group were kept unchanged. Since the rock temperature in Sanhejian Coal Mine at the depth of $-700 \mathrm{~m}$ is $37.7-40^{\circ} \mathrm{C}$, in this experiment, the virgin rock temperature was set as $38^{\circ} \mathrm{C}$. In addition, the airflow speed was $3 \mathrm{~m} / \mathrm{s}$; the temperature of the inlet airflow was $20^{\circ} \mathrm{C}$; and the humidity of the inlet airflow was $20 \%$.

In Sanhejian Coal Mine, since the flow rate of trickling water within the range of $16 \mathrm{~m}$ shall not exceed $3 \mathrm{~m}^{3} / \mathrm{h}$, the flow rate of fracture water shall not exceed $250 \mathrm{ml} / \mathrm{min}$ in this experiment according to the similarity ratio. The highest temperatures of trickling water are $60-70^{\circ} \mathrm{C}$ in coal mines (e.g., $65^{\circ} \mathrm{C}$, Pingdingshan No. 8 Mine) and $70-80^{\circ} \mathrm{C}$ in metal mines (e.g., $73.5^{\circ} \mathrm{C}$, Jiudian Gold Mine). Based on this fact, five experimental schemes were designed, as listed in Table 3. 


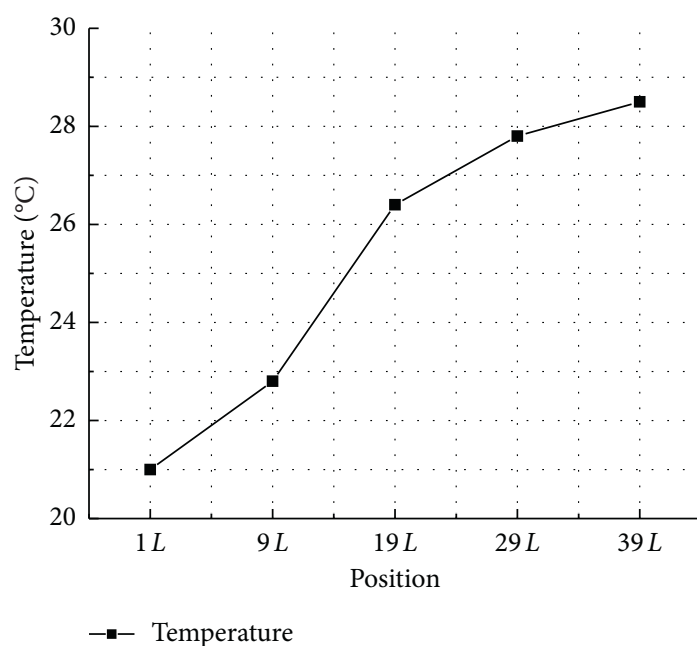

(a)

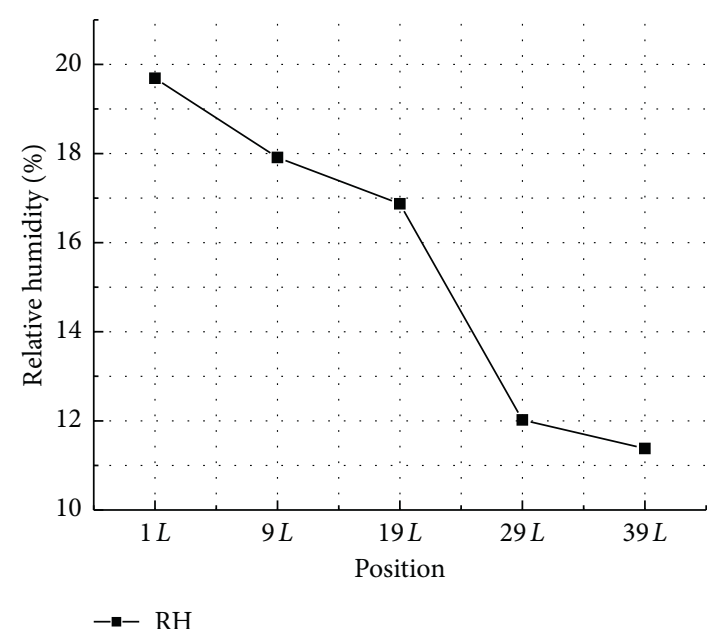

(b)

FIgURE 6: Initial conditions of airflow before trickling.

TABle 3: Experimental scheme.

\begin{tabular}{lccccc}
\hline Variable & Scheme 1 & Scheme 2 & Scheme 3 & Scheme 4 & Scheme 5 \\
\hline Water flow rate $(\mathrm{ml} / \mathrm{min})$ & 50 & 100 & 200 & 100 & 100 \\
Water temperature $\left({ }^{\circ} \mathrm{C}\right)$ & 60 & 60 & 60 & 40 & 80 \\
\hline
\end{tabular}

3.2.2. Experimental Procedures. The tests were conducted in accordance with the following steps: (1) to heat surrounding rock to $38^{\circ} \mathrm{C}$ by the SRHS; (2) to regulate parameters of inlet airflow by the CTHV $\left(t=20^{\circ} \mathrm{C}, R H=20 \%, v=3 \mathrm{~m} / \mathrm{s}\right)$ and maintain ventilation until the surrounding rock-airflow system reach heat balance-airflow parameters at this moment are disclosed in Figure 6-(3) to provide the required trickling conditions by the pump and to keep the ventilation and trickling state for $180 \mathrm{~min}$; and (4) to record the temperature and $\mathrm{RH}$ of airflow in the $1 L-39 L$ section. By this above procedure, tests were conducted under varying trickling conditions in Schemes 1-5. In the tests, the effect of thermal water on the surrounding rock temperature was ignored.

3.3. Calculation of Enthalpy. During $180 \mathrm{~min}$ water flow supplying to the $1 L-39 L$ section, heat and mass transfer promoted by the enthalpy difference occurs between airflow and trickling thermal water [37]. Humid air absorbs/releases heat from/to the surrounding medium when the enthalpy difference is positive/negative. The enthalpy of humid air, expressed based on $1 \mathrm{~kg}$ of dry air, is the sum of the enthalpies of $1 \mathrm{~kg}$ of dry air and $d \mathrm{~kg}$ of water vapor. The enthalpy of humid air is

$$
i=1.0045 t_{d}+d \cdot\left(2501+1.85 t_{d}\right)
$$

where $1.0045 t_{d}$ is the enthalpy of $1 \mathrm{~kg}$ of dry air, $\mathrm{kJ} / \mathrm{kg}$; $d$ is the humidity ratio in air, $\mathrm{kg} / \mathrm{kg} ; 2501$ is the latent heat of vaporization of water vapor, $\mathrm{kJ} / \mathrm{kg} ; 1.85$ is the average specific heat at a constant pressure of water vapor at normal temperature, $\mathrm{kJ} /(\mathrm{kg} \cdot \mathrm{K})$; and $t_{d}$ is dry bulb temperature, ${ }^{\circ} \mathrm{C}$. The humidity ratio in air $d$ is

$$
\begin{aligned}
d & =0.622 \frac{\varphi f_{1}}{P_{1}-\varphi f_{1}}, \\
f_{1} & =0.6099 e^{17.27 t_{d} / 237.3+t_{d}},
\end{aligned}
$$

where $\varphi$ is the relative humidity of air, $\% ; P_{1}$ is the atmospheric pressure, $\mathrm{kPa}$; and $f_{1}$ is the saturated vapor pressure of air at the temperature $t_{d}, \mathrm{kPa}$.

\section{Results and Discussion}

4.1. Temperature and Relative Humidity Variations. The airflow temperature rarely varies when the trickling water is of low temperature and low flow rate, while it rises remarkably when the trickling water is of high temperature and high flow rate. Under the five trickling conditions, the temperature at $1 L$ along the axial direction of the cylinder decreases by about $0.5^{\circ} \mathrm{C}$. When the temperature is lower $\left(<60^{\circ} \mathrm{C}\right)$ or the flow rate is lower $(<100 \mathrm{ml} / \mathrm{min})$, the temperatures at $9 L, 19 L, 29 L$, and $39 L$ rise slightly within the range of $0.6^{\circ} \mathrm{C}$. In contrast, the maximum temperature rise can be $2.37^{\circ} \mathrm{C}$ (Figure 7 (a) under the trickling condition of $100-80 \quad\left(100-80\right.$ refers to $100 \mathrm{ml} / \mathrm{min}-80^{\circ} \mathrm{C}$, hereinafter described in the same form).

As shown in Figure 7(b), after thermal water supplying, the relative humidity in the $9 L-39 L$ section is all notably higher than the initial value (Figure 6(b)), and the value at $19 L$ is the greatest, followed by those at $29 L$ and $39 L$ in turn 


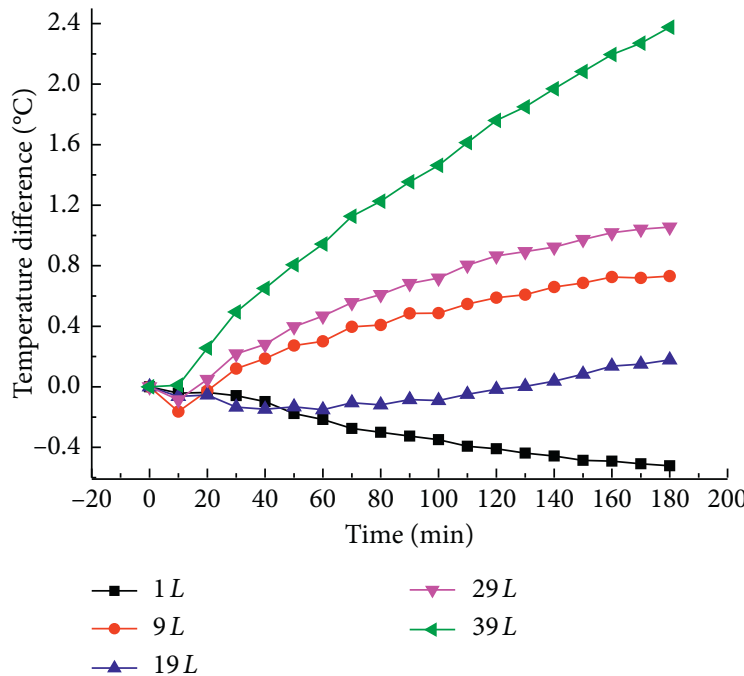

(a)

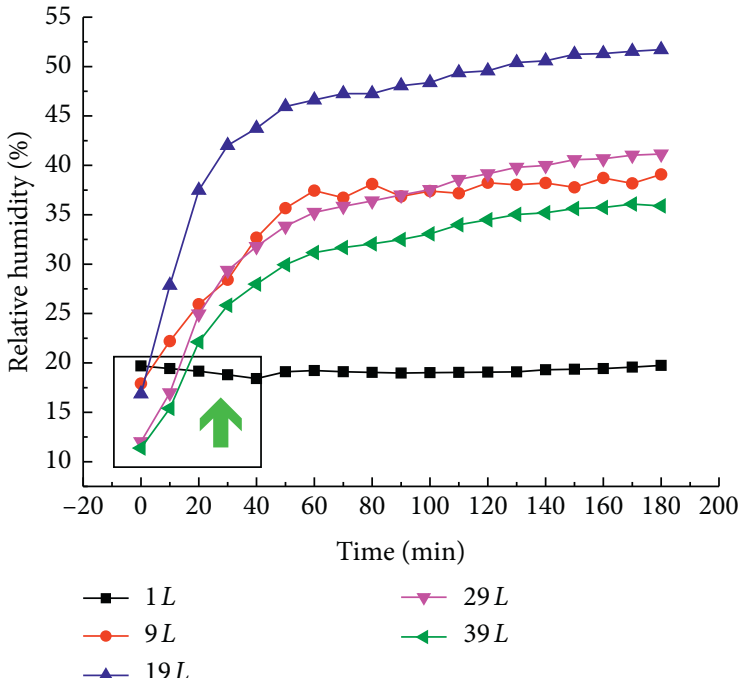

(b)

Figure 7: Temperature difference and relative humidity variations at different measuring points. (a) $100 \mathrm{ml} / \mathrm{min}-80^{\circ} \mathrm{C}$. (b) $200 \mathrm{ml} / \mathrm{min}-60^{\circ} \mathrm{C}$.

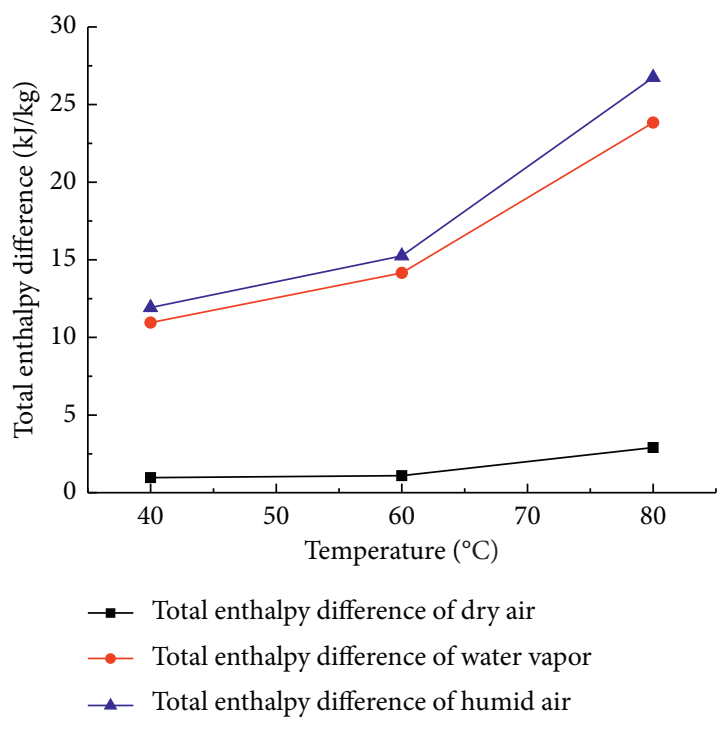

(a)

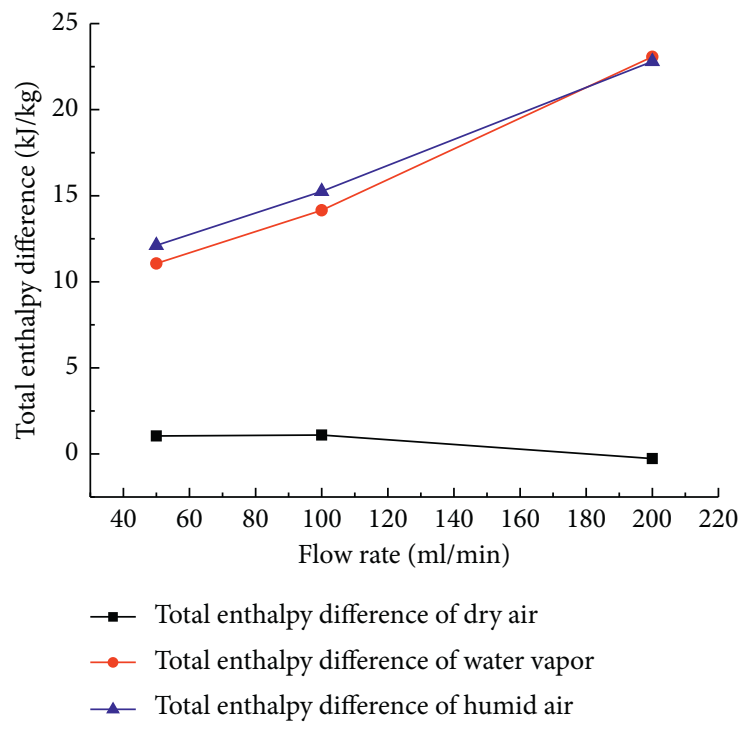

(b)

FIgURE 8: Total enthalpy difference variations of the trickling roadway. (a) $Q=100 \mathrm{ml} / \mathrm{min}$. (b) $T=60^{\circ} \mathrm{C}$.

all the time. Before thermal water supplying, the relative humidity in the $1 L-39 L$ section declines and is lower than $20 \%$ of the initial value. This is because the humidity ratios in this section are basically equal $(0.003-0.004 \mathrm{~kg} / \mathrm{kg})$, but the saturated steam pressure $f_{1}$ along the axial direction rises. After water flow supplying, the relative humidity in the $9 L-39 L$ section grows (the growth rates gradually decrease). Among the five measuring points, the relative humidity of $19 \mathrm{~L}$ is the largest, reaching up to $51.7 \%$ under the condition of 200-60 (Figure 7(b)). The reason for this distribution characteristic is that when the airflow passes through the $1 L-9 L$ water trickling section, the evaporation of water film results in the maximum value of the water vapor pressure at
19L. However, the relative humidity keeps falling in the $9 L-39 L$ section for two reasons: first, the water vapor pressures at $29 \mathrm{~L}$ and $39 \mathrm{~L}$ are lower than those at $19 \mathrm{~L}$. Second, the saturated steam pressure $f_{1}$ is higher than that at $19 L$.

\subsection{Enthalpy Difference Variation}

\subsubsection{Total Enthalpy Difference Variation of Trickling} Roadway. The total enthalpy difference of airflow, which represents the variation of airflow energy, is the impetus of heat and mass transfer. It can be calculated through the following equation: 


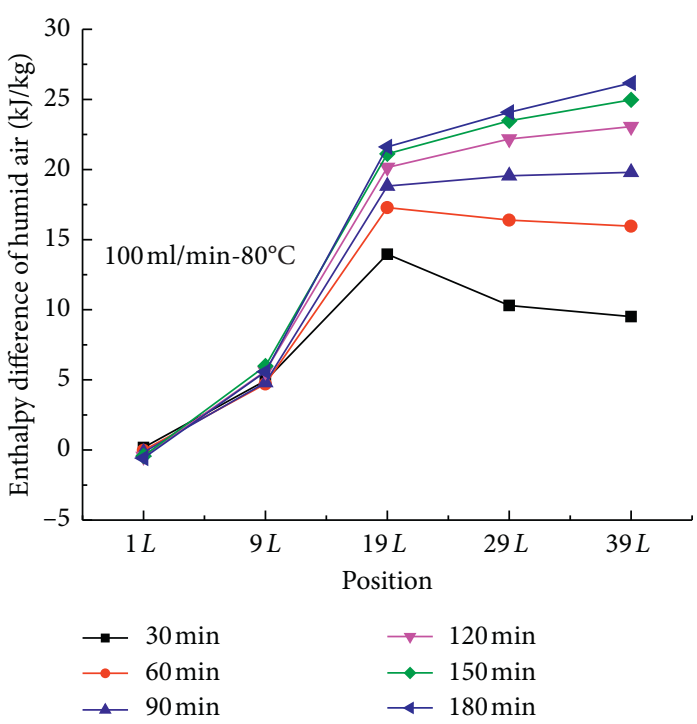

(a)

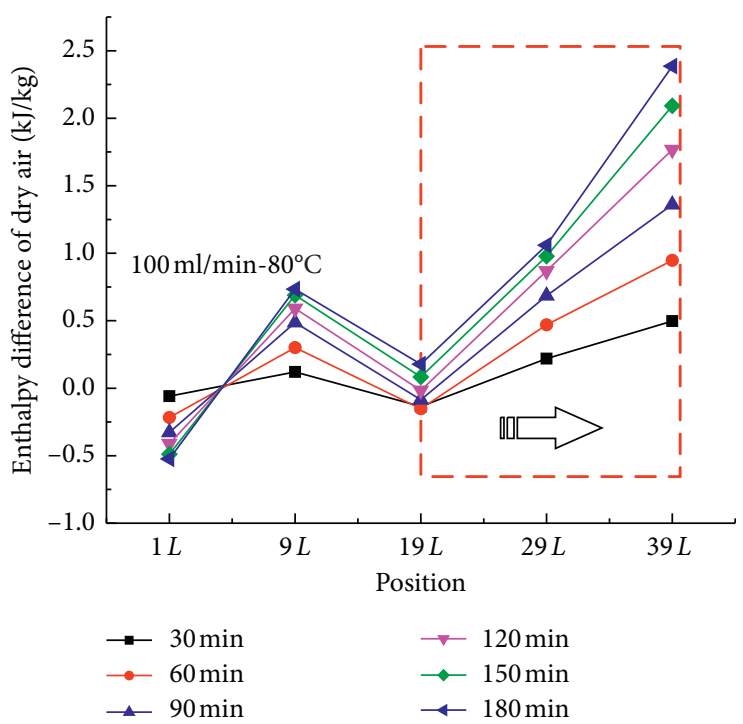

(c)

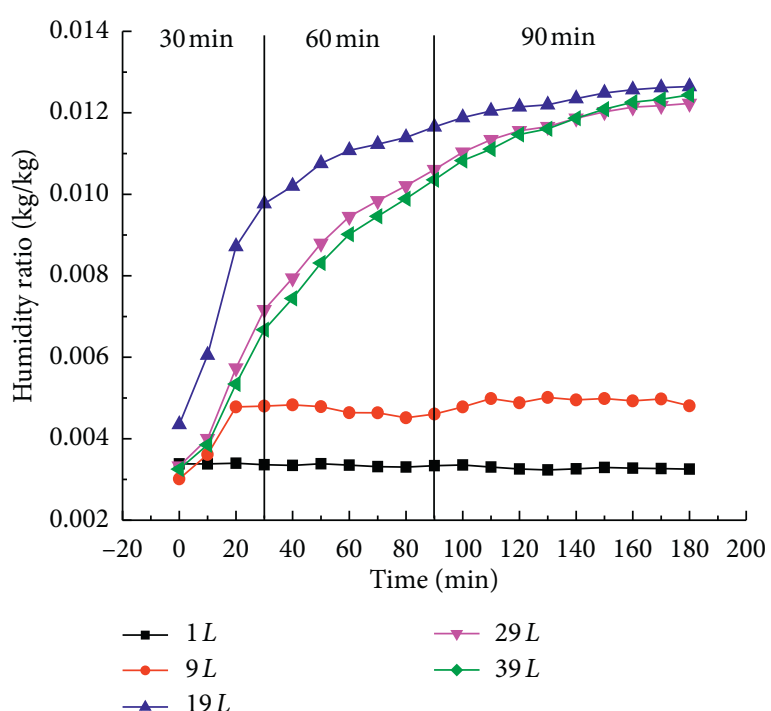

(b)

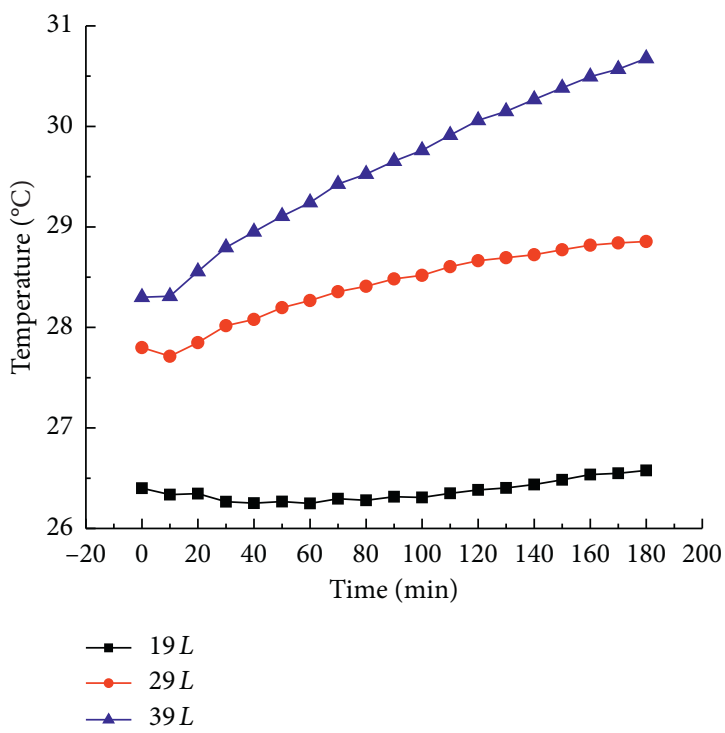

(d)

FIGURE 9: Analysis of the enthalpy difference variations at $19 \mathrm{~L}, 29 \mathrm{~L}$, and $39 \mathrm{~L}$ under the condition of $100-80$.

$$
\Delta i=\Delta i_{5}-\Delta i_{1}=\left(i_{5-180}-i_{5-0}\right)-\left(i_{1-180}-i_{1-0}\right),
$$

where $\Delta i$ is the enthalpy difference, $\mathrm{kJ} / \mathrm{kg} ; \Delta i_{5}$ is the enthalpy difference at $39 L$ during water flow supplying; $i_{5-180}$ is the enthalpy value at $39 L$ at the end of water flow supplying; $i_{5-0}$ is the enthalpy value at $39 \mathrm{~L}$ at the beginning of water flow supplying; $\Delta i_{1}$ is the enthalpy difference at $1 L$ during water flow supplying; $i_{1-180}$ is the enthalpy value at $1 L$ at the end of water flow supplying; and $i_{1-0}$ is the enthalpy value at $1 L$ the beginning of water flow supplying.

The curves of total enthalpy difference variations under the five trickling conditions are presented in Figure 8 . The rise of trickling water temperature causes an increase in both the sensible heat and the latent heat of the airflow (Figure 8(a)). At the same trickling water flow rate $(100 \mathrm{ml} / \mathrm{min})$, the total enthalpy difference of dry air increases within a small range, while that of humid air goes upward nonlinearly with the rise of trickling water temperature. The increase of trickling water flow rate has an insignificant effect on the sensible heat of the airflow, while it plays a notable role in increasing the latent heat of the airflow (Figure $8(\mathrm{~b}))$. At the same temperature $\left(60^{\circ} \mathrm{C}\right)$, the enthalpy difference of dry air fluctuates, while that of humid air goes upward linearly with the rise of trickling water flow rate.

4.2.2. Enthalpy Difference Variation Rate at Each Point under the Condition of High Trickling Temperature and High Flow Rate. Figures 9(a) and 9(c) display the curves of enthalpy difference variations of humid air and dry air at different times with position under the condition of 100-80 (here, the 


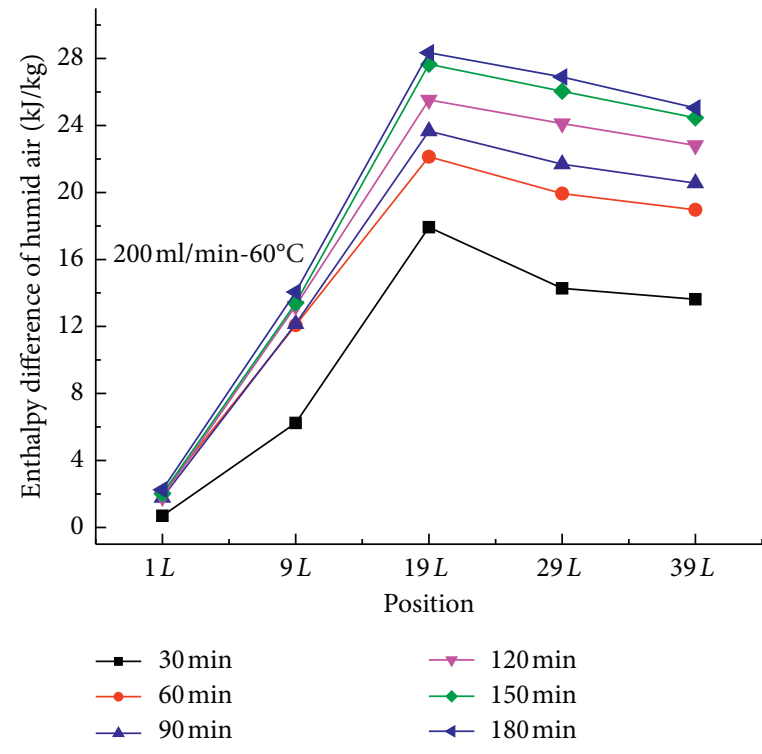

(a)

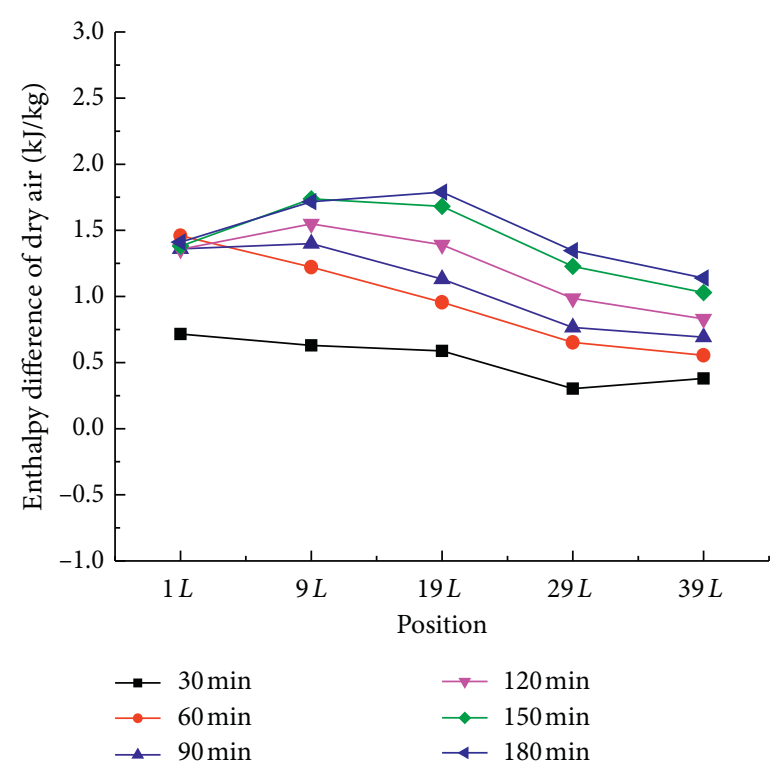

(b)

Figure 10: Analysis of the enthalpy difference variations at $19 L-39 L$ under the condition of 200-60.

enthalpy difference refers to the difference between the initial enthalpy value and the final one at different times at the same position). Figure 9(b) shows the variations of humidity ratios at various measuring points. It can be concluded that the humidity ratio at $19 \mathrm{~L}$ changes more and more slowly with time, and the increases of humidity ratios at $29 \mathrm{~L}$ and $39 \mathrm{~L}$ experience a hysteretic process. At the end of water flow supplying, the humidity ratios at the three points become basically the same. The hysteretic process causes the higher relative humidity growth rate at $19 \mathrm{~L}$ than those at $29 \mathrm{~L}$ and $39 \mathrm{~L}$ in the first $30 \mathrm{~min}$ (Figure $7(\mathrm{~b})$ ). Figure $9(\mathrm{~d})$ discloses the change curve of dry bulb temperature during water flow supplying at $19 \mathrm{~L}, 29 \mathrm{~L}$, and $39 \mathrm{~L}$. It can be seen that the temperature difference between $39 \mathrm{~L}$ and $19 \mathrm{~L}$ gradually increases.

High trickling water temperature (e.g., $80^{\circ} \mathrm{C}$ ) significantly affects the enthalpy difference variation rates of wet air at $19 L, 29 L$, and $39 L$ with time. The variation rates at the three points differ remarkably before the surrounding rock-airflow system reaches heat balance (Figure 9(a)). The enthalpy difference of wet air comes from both sensible heat and latent heat. The change in sensible heat, positively correlated with the temperature difference, is represented by the enthalpy difference of dry air. In contrast, the change in latent heat, positively correlated with the humidity ratio, is represented by the enthalpy difference of water vapor. (1) In the first $30 \mathrm{~min}$ of thermal water trickling, the enthalpy difference of humid air at $19 \mathrm{~L}$ is the largest. In this stage, due to the high growth rate of humidity ratio at $19 L$, the enthalpy difference of water vapor surges rapidly. As shown in Figure 9(b), the humidity ratio at $19 L$ is $0.003 \mathrm{~kg} / \mathrm{kg}$ greater than that at $39 \mathrm{~L}$ at $30 \mathrm{~min}$. Nevertheless, the enthalpy differences of dry air at the three points differ slightly. (2) After thermal water trickles for 30-90 min, the enthalpy differences of humid air at $29 L$ and $39 L$ increase, and the differences at the three points become basically equal at $90 \mathrm{~min}$. In this stage, $29 \mathrm{~L}$ and $39 \mathrm{~L}$ have already passed the hysteretic period. Their humidity ratios grow at higher rates than that at $19 L$, and their enthalpy differences of dry air surge. As shown in Figure $9(\mathrm{~d})$, the temperature at $39 \mathrm{~L}$ is $3.34^{\circ} \mathrm{C}$ higher than that at $19 \mathrm{~L}$ at $90 \mathrm{~min}$. (3) After thermal water trickles for over $90 \mathrm{~min}$, the enthalpy difference of humid air at $39 \mathrm{~L}$ becomes the largest. In this stage, the amounts of latent heat exchange at the three points all reach their high values. Meanwhile, their humidity ratios rise synchronously at $180 \mathrm{~min}$. However, because of the continuously increasing amounts of sensible heat exchange, the enthalpy difference of humid air at $39 \mathrm{~L}$ is $4.56 \mathrm{~kJ} / \mathrm{kg}$ greater than that at $19 \mathrm{~L}$ after the end of water flow supplying.

Figure 10 presents curves of enthalpy difference variations of humid air and dry air at different times during water flow supplying under the condition of 200-60. High trickling water flow rate (e.g., $200 \mathrm{ml} / \mathrm{min}$ ) will not remarkably alter the enthalpy difference variation rates of humid air at $19 \mathrm{~L}, 29 \mathrm{~L}$, and $39 \mathrm{~L}$ with time (Figure 10(a)). A high trickling water flow rate leads to small ranges of temperature rise at the three points, and the amounts of sensible heat at the three points do not differ much (Figure 10(b)). In other words, the enthalpy differences of humid air at $19 L, 29 L$, and $39 L$ are mainly influenced by latent heat. (1) In the first $30 \mathrm{~min}$ of thermal water trickling, the enthalpy difference of humid air at $19 \mathrm{~L}$ is the largest. In this stage, due to the high growth rate of humidity ratio at $19 \mathrm{~L}$, the enthalpy difference of water vapor surges rapidly. A comparison between Figure 11 and Figure 9(b) reveals that the increases in the humidity ratio at $29 \mathrm{~L}$ and $39 \mathrm{~L}$ present no obvious hysteretic 


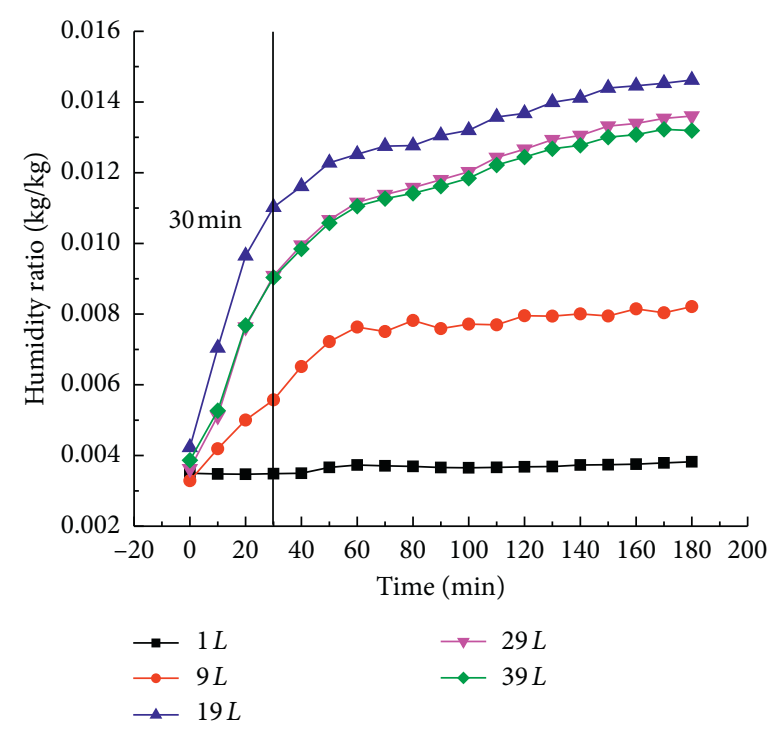

FIgURE 11: Analysis of the humidity ratio variations at $19 L-39 L$ under the condition of 200-60.

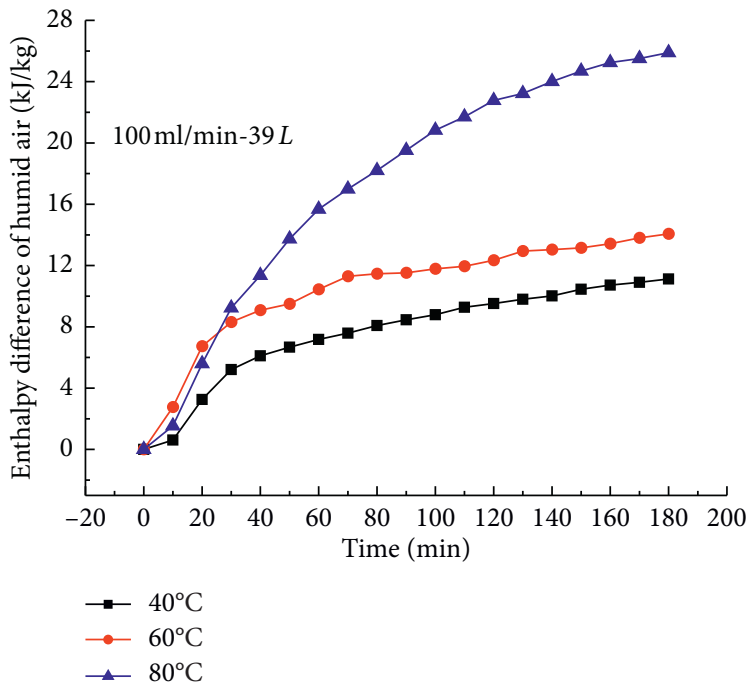

(a)

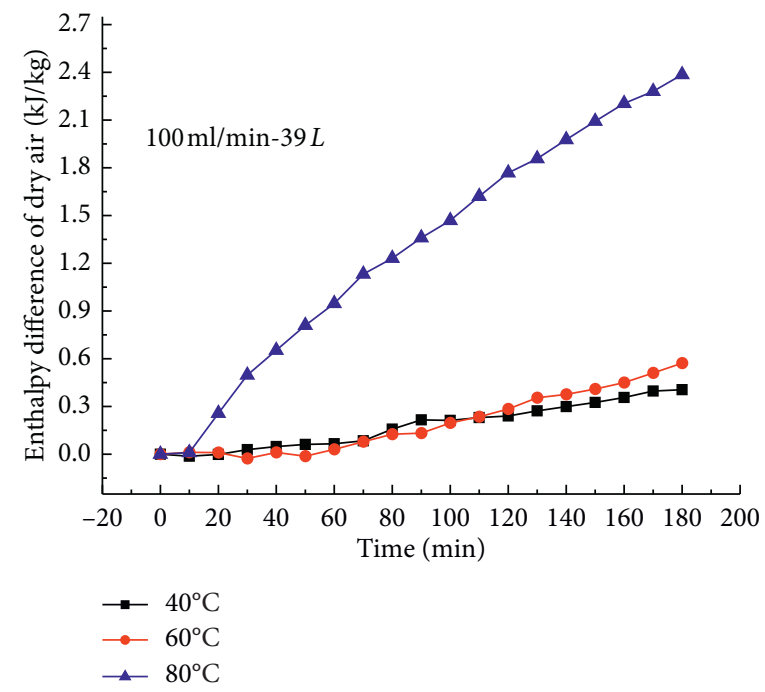

(b)

FIgure 12: Curves of enthalpy difference variations at different temperatures under the condition of $100 \mathrm{ml} / \mathrm{min}$.

processes. (2) After thermal water trickles for over $30 \mathrm{~min}$, the enthalpy difference of humid air at $19 \mathrm{~L}$ remains the largest. In addition, the enthalpy difference growth rates of humid air at $19 L, 29 L$, and $39 L$ do not differ notably at a certain moment because the humidity ratios at the three points rise synchronously after $30 \mathrm{~min}$ (Figure 11).

Evidently, high trickling water temperature results in a higher growth rate of humidity ratio at $19 \mathrm{~L}$ than those at $29 \mathrm{~L}$ and $39 L$ in the early stage of thermal water trickling. Meanwhile, sensible heat exchange complicates the enthalpy difference variation rates of humid air at the three points, which is clearly exhibited after thermal water trickles for over $30 \mathrm{~min}$. These facts bring difficulty to the temperature and humidity prediction of the trickling roadway.
4.2.3. Enthalpy Difference Variations at 39L with Different Trickling Temperatures and Flow Rates. After the airflow passes through the trickling section, enthalpy difference variations at $39 L$ with trickling water temperature and flow rate are shown in Figures 12 and 13, respectively. The enthalpy difference at $39 \mathrm{~L}$ grows with time during water flow supplying. Besides, the enthalpy difference of humid air at $39 \mathrm{~L}$ rises as well with the increases of trickling water temperature and flow rate.

When the trickling water flow rate is $100 \mathrm{ml} / \mathrm{min}$, the dry air enthalpy difference at $39 \mathrm{~L}$ is $0.4-0.6 \mathrm{~kJ} / \mathrm{kg}$ under the conditions of $40^{\circ} \mathrm{C}$ and $60^{\circ} \mathrm{C}$. When the trickling water temperature is $80^{\circ} \mathrm{C}$, the enthalpy difference of dry air at $39 \mathrm{~L}$ surges sharply to $2.38 \mathrm{~kJ} / \mathrm{kg}$, and that of humid air at $39 \mathrm{~L}$ jumps significantly as well (Figure 12(a)). 


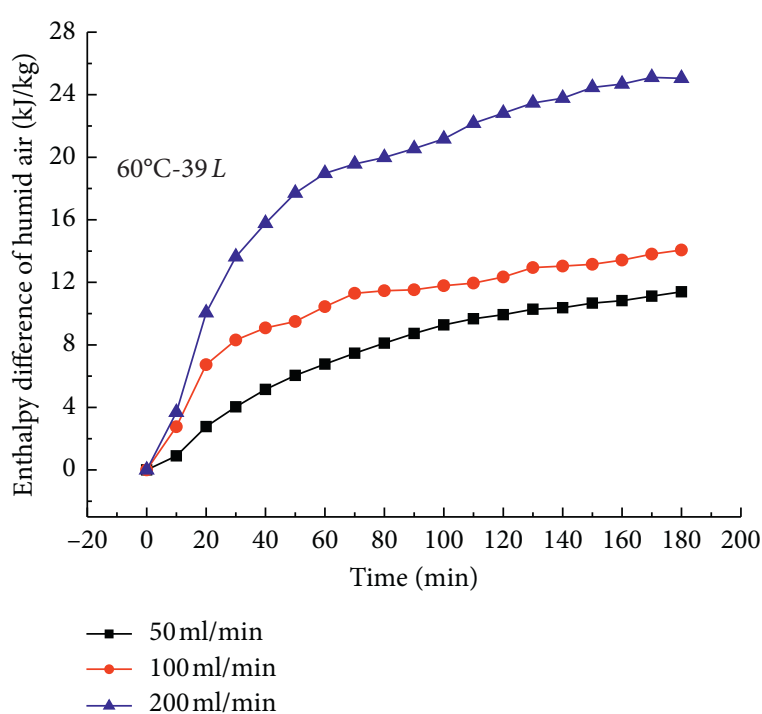

(a)

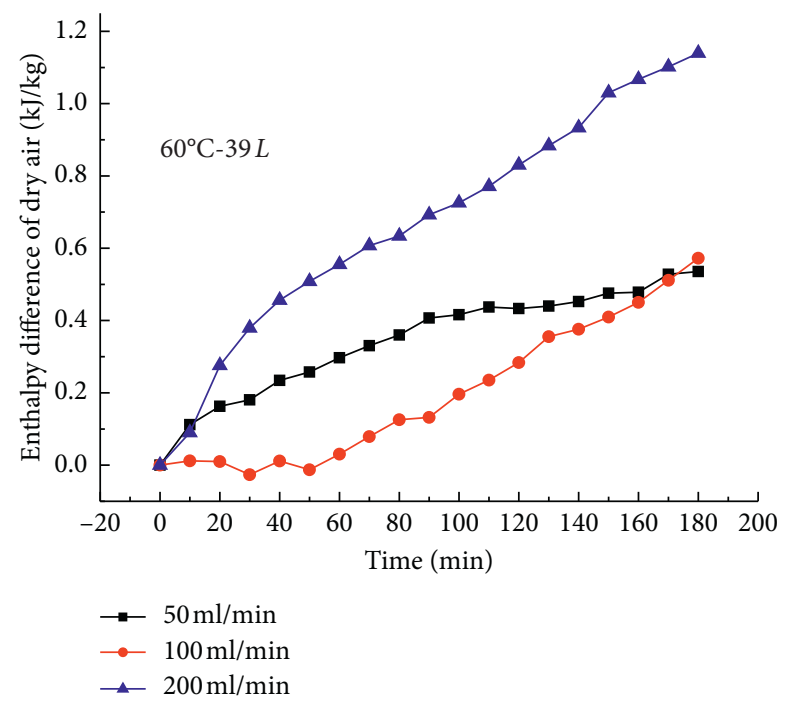

(b)

Figure 13: Curves of enthalpy difference variations at different flow rates under the condition of $60^{\circ} \mathrm{C}$.

When the trickling water temperature is $60^{\circ} \mathrm{C}$, the dry air enthalpy difference at $39 \mathrm{~L}$ is $0.57 \mathrm{~kJ} / \mathrm{kg}$ under the conditions of $50 \mathrm{ml} / \mathrm{min}$ and $100 \mathrm{ml} / \mathrm{min}$. When the trickling water flow rate is $200 \mathrm{ml} / \mathrm{min}$, the enthalpy difference of dry air at $39 \mathrm{~L}$ increases by $1.1 \mathrm{~kJ} / \mathrm{kg}$, and that of humid air at $39 \mathrm{~L}$ soars (Figure 13(a)).

\section{Conclusions}

Thermal hazards in Sanhejian Coal Mine are mainly caused by high geo-temperature field and thermal water upwelling. Field measurement results suggest that thermal water trickling to roadway has a significant impact on the mine microclimate. In this paper, a similarity experiment was performed for investigating the influence of thermal water trickling on airflow parameters of a section of roadway. Several beneficial conclusions were drawn. The research results allow the prediction of temperature and $\mathrm{RH}$ to be deliberated:

(1) The total enthalpy difference variation of the trickling roadway was analyzed. With the rise of trickling water temperature, the total enthalpy difference of dry air in the roadway increases within a small range, and that of humid air goes up nonlinearly. Besides, the rise of trickling water flow rate has an insignificant effect on the sensible heat of the airflow, while it plays a notable role in increasing the latent heat of the airflow.

(2) The enthalpy difference variation rates at different measuring points were compared under the condition of high trickling water temperature and flow rate. High trickling water flow rate (e.g., $200 \mathrm{ml} / \mathrm{min}$ ) will not cause notably varying enthalpy difference variation rates of humid air with time at $19 \mathrm{~L}, 29 \mathrm{~L}$, and $39 L$, but the variation rates at the three points differ remarkably before the surrounding rock-airflow system reach heat balance under the condition of high trickling water temperature (e.g., $80^{\circ} \mathrm{C}$ ). Evidently, high trickling water temperature results in a higher growth rate of humidity ratio at $19 \mathrm{~L}$ than those at $29 \mathrm{~L}$ and $39 \mathrm{~L}$ in the early stage of thermal water trickling. Meanwhile, sensible heat exchange, which becomes strong after thermal water trickles for over $30 \mathrm{~min}$, complicates the enthalpy difference variation rates of humid air at the three points.

(3) The curves of temperature and RH variations with time at $19 L, 29 L$, and $39 L$ under the five schemes were recorded. The three points all display a process of enthalpy growth with time. For example, for $39 \mathrm{~L}$, the enthalpy difference of humid air surges sharply when the trickling water temperature is $80^{\circ} \mathrm{C}$ or the flow rate is $200 \mathrm{ml} / \mathrm{min}$.

\section{Data Availability}

The data used to support the findings of this study are available from the corresponding author upon request.

\section{Conflicts of Interest}

The authors declare no conflicts of interest.

\section{Acknowledgments}

The authors are grateful to Dr. Zhaoyang Ma from Monash University for his support and contribution to language proofreading. This research was funded by National Natural Science Foundation of China, under Grant no. 51674242. 


\section{References}

[1] K. Carpenter, P. Roghanchi, and C. Kocsis, "Investigating the importance of climatic monitoring and modeling in deep and hot US underground mines," in Proceedings of the 15th North American Mine Ventilation Symposium, pp. 1-4, Blacksburg, VA, USA, June 2015.

[2] B. Belle and M. Biffi, "Cooling pathways for deep Australian longwall coal mines of the future," International Journal of Mining Science and Technology, vol. 28, no. 6, pp. 865-875, 2018.

[3] X. J. Yang, Q. Y. Han, J. W. Pang et al., "Progress of heathazard treatment in deep mines," International Journal of Mining Science and Technology, vol. 21, no. 2, pp. 295-299, 2011.

[4] N. Slazak, D. Obracaj, and M. Borowski, "Methods for controlling temperature hazard in Polish coal mines," Archives of Mining Sciences, vol. 53, no. 4, pp. 497-510, 2008.

[5] M. He, X. Cao, Q. Xie et al., "Principles and technology for stepwise utilization of resources for mitigating deep mine heat hazards," Mining Science and Technology (China), vol. 20, no. 1, pp. 20-27, 2010.

[6] Y. Sun, G. Li, H. Basarir et al., "Laboratory evaluation of shear strength properties for cement-based grouted coal mass," Arabian Journal of Geosciences, vol. 12, no. 22, p. 690, 2019.

[7] Y. Zhang, Z.-j. Wan, B. Gu, C.-b. Zhou, and J.-y. Cheng, "Unsteady temperature field of surrounding rock mass in high geothermal roadway during mechanical ventilation," Journal of Central South University, vol. 24, no. 2, pp. 374-381, 2017.

[8] H. P. Kang, G. F. Wang, P. F. Jiang et al., "Conception for strata control and intelligent mining technology in deep coal mines with depth more than $1000 \mathrm{~m}$," Journal of China Coal Society, vol. 43, no. 7, pp. 1789-1800, 2018.

[9] Q. Y. Han, Y. Zhang, K. Q. Li et al., "Computational evaluation of cooling system under deep hot and humid coal mine in China: a thermal comfort study," Tunnelling and Underground Space Technology, vol. 90, pp. 394-403, 2019.

[10] B. Głuch, "Equivalent climate temperature analysis as a criterion of climate hazard evaluation in Polish underground mines," Archives of Mining Sciences, vol. 63, pp. 975-988, 2018.

[11] J. Y. Wang, Geothermology and its Application, Science press, Beijing, China, 2015.

[12] J. Bundschuh and B. Tomaszewska, Geothermal Water Management, CRC Press, Boca Raton, FL, USA, 2018.

[13] Y. Zhang, Transient Temperature Field of Surrounding Rock of the High Geothermal Roadway and its Heat Control Mechanism by Heat Insulation, China University of Mining and Technology, Xuzhou, China, 2013.

[14] Y. Q. Cen, C. S. Hu, and Q. Z. Hou, "Investigation into unsteady heat transfer coefficient $\mathrm{K}$ between the surrounding rock of mine wells or lanes and airflow," Journal of Liaoning Technical University, vol. 6, no. 3, pp. 105-114, 1987.

[15] X. H. Zhou, Y. F. Shan, and J. R. Wang, "The unsteady thermal exchange between wall rock and airflow of roadway," Journal of Liaoning Technical University (Natural Science Edition), vol. 21, no. 3, pp. 264-266, 2002.

[16] P. D. Sun, "A new method for calculating the instable heat transfer coefficient," Journal of China University of Mining \& Technology, vol. 20, no. 2, pp. 33-37, 1991.

[17] A. K. Yakovenko and G. V. Averin, "Determination of the heat-transfer coefficient for a rock mass with small Fourier numbers," Soviet Mining Science, vol. 20, no. 1, pp. 52-56, 1984.
[18] Y.-j. Wang, G.-q. Zhou, and L. Wu, "Unsteady heat-moisture transfer of wet airway in deep mining," Journal of Central South University, vol. 20, no. 7, pp. 1971-1977, 2013.

[19] Y. P. Qin and F. H. Qin, "Compution the unsteady-state heat transfer criterion between air and rock surrounding airway with finite difference method," Journal of Xiangtan Mining Institute, vol. 13, pp. 6-10, 1998.

[20] T. R. Roy and B. Singh, "Computer simulation of transient climatic conditions in underground airways," Mining Science and Technology, vol. 13, no. 3, pp. 395-402, 1991.

[21] J. X. Wang, X. H. Guo, and S. K. He, "Computation of the unsteady heat (between country rock and air flow) and oxidation exothermic heat in the thermal stope," Journal of Hebei Mining and Civil Engineering Institute, vol. 3, pp. 18-23, 1995.

[22] W. M. Cheng, F. M. Zhuge, G. Zhou et al., "Improved momentum BP algorithm to calculate air flow unstable heat conducted coefficient of surrounding rocks," Coal Science and Technology, vol. 37, no. 12, pp. 35-37, 2009.

[23] L. C. Chow and J. N. Chung, "Evaporation of water into a laminar stream of air and superheated steam," International Journal of Heat and Mass Transfer, vol. 26, no. 3, pp. 373-380, 1983.

[24] Q. Hou and B. Shen, "The prediction model of temperature and moisture transfer between tunnel periphery rock and air," Journal of Wuhan University of Technology, vol. 19, no. 3, pp. 123-127, 1997.

[25] H. Q. Liu, H. Wang, and X. W. Shao, "Analysis and a simplified calculation method of the thermo-moisture exchange between the hot mining roadway wall and the airflow," Journal of Safety and Environment, vol. 12, no. 3, pp. 208-212, 2012.

[26] J. Gao, W. Xu, and X. Zhang, "Treatment of water evaporation during calculation of temperature and humidity of airflow caused by heat release from surrounding rock," Journal of China Coal Society, vol. 35, no. 6, pp. 28-32, 2010.

[27] C. Shi, S. Bu, L. Zhang et al., "Experimental and numerical investigation on the evaporation performance of a cyclonetype spray desalination chamber," Desalination, vol. 467, pp. 125-135, 2019.

[28] X. Xie, H. Liu, C. He, B. Zhang, Q. Chen, and M. Pan, "Deciphering the heat and mass transfer behaviors of staggered tube bundles in a closed wet cooling tower using a 3-D VOF model," Applied Thermal Engineering, vol. 161, p. 114202, 2019.

[29] Y. Wang, Y. Jiang, W. Chen, and B. Zhou, "Heat transfer characteristics of spray cooling beyond critical heat flux under severe heat dissipation condition," Applied Thermal Engineering, vol. 123, pp. 1356-1364, 2017.

[30] Y. J. Wang, G. Q. Zhou, Y. Z. Wei et al., "Experimental research on changes in the unsteady temperature field of an airway in deep mining engineering," Journal of China University of Mining \& Technology, vol. 40, no. 3, pp. 345-350, 2011.

[31] Y. Zhang, Z. Wan, B. Gu et al., "An experimental investigation of transient heat transfer in surrounding rock mass of high geothermal roadway," Thermal Science, vol. 20, no. 6, p. 53, 2016.

[32] S. Zhu, S. Wu, J. Cheng, S. Li, and M. Li, "An underground airroute temperature prediction model for ultra-deep coal mines," Minerals, vol. 5, no. 3, pp. 527-545, 2015.

[33] H. Z. Wang, "Study on characteristics of heat and mass transfer in working face of high-temperature mine," M. Sc thesis, China University of Mining and Technology, Xuzhou, China, 2016. 
[34] F. H. Chu, T. Yue, M. D. Yu et al., "Analysis on water inrush gelogical conditon in Sanhejian coal mine of Xuzhou Mine Area," Coal Science and Technology, vol. 42, pp. 223-225, 2014.

[35] R. Li and X. D. Huang, "Study on geothermal anomalies in Sanhejian coal field," Jiangsu Coal, vol. 3, pp. 23-24, 1998.

[36] X. J. Yang, Q. Y. Han, Y. H. Tian et al., "Mechanism of hightemperature heat-hazard at Sanhejian coal mine, Xuzhou," Chinese Journal of Rock Mechanics and Engineering, vol. 32, no. 12, pp. 2447-2454, 2013.

[37] A. Bacardit, J. M. Morera, L. Ollé et al., Mine Ventilation and Air Conditioning, John Wiley \& Sons Press, Hoboken, NJ, USA, 2012. 